\title{
DETERMINANTS AND DIRECTIONS OF THE TRANSITION FROM TRADITIONAL TO SUSTAINABLE AGRICULTURE: THE BULGARIAN CASE Julia Doitchinova ${ }^{1}$, Albena Miteva ${ }^{2}$, Darina Zaimova ${ }^{3}$
}

\begin{abstract}
On the basis of a literature review, the directions for transition of agriculture from the productive to the postproductive model are presented. A methodological framework has been developed, including the directions of the transition and the indicators on which it can be assessed. On the basis of this implementation, the passage from quantity to production quality, to the sustainability of agriculture, to new business models based on multifunctionality are assessed. It turns out that the changes in Bulgarian agriculture cannot be assessed unambiguously. The transition to sustainability is accompanied by continued mechanization and digitization of technological processes. There is a simultaneous development of both the productive and the post-productive model of agriculture. Together with the increasing interest in organic production, the implementation of environmentally friendly practices and the implementation of ecosystem services, modernization based on computerization and chemisation continues.
\end{abstract}

The results are part of scientific project DN 15/8 2017 Sustainable multifunctional rural areas: reconsidering agricultural models and systems with increased demands and limited resources funded by the Bulgarian research fund.

JEL Classification Numbers: O13, Q16, Q56, DOI: 10.12955/cbup.v7.1343

Keywords: sustainability, multifunctionality, model of agriculture

\section{Introduction}

The model of agriculture at the end of the 20th century is based on the productive farming regime. Its characteristics - the strictly defined position of the agriculture in the community, the industrialized and specialized production under the conditions of a protectionist agrarian policy - have become one of the main reasons for the negative trends in the socio-economic, ecological, demographic and other processes.

The authors point out that "the rapid pace of concentration of agricultural production and the increasing polarization of agricultural structures has led to significant problems both in intensive farming areas and in disadvantaged areas" (EC, 2010, 2011). The deepening of specialization, intensification and concentration of agriculture are the reason for the increase of the uniform production areas, the nonrational use of natural resources, the increase of the negative impacts of the activity and the standardization of the nutritional qualities of a number of products.

Many authors (Knickel, 1990, 1997; Knickel et al., 2013) analyzed and periodically reviewed this problem for almost twenty-five years and argued that the concentration of production and well-being in some regions and on farms is contradictory to the goal of a more balanced overall development, as it is directly linked to the marginalization of other regions and farms. Continued drive to reduce production costs to keep production competitive, puts constant pressure on food quality, environmental standards and working conditions.

The EU Common Agricultural Policy also has a major impact on production patterns. In a number of newly acceded countries, it has contributed substantially to the dramatic structural changes in agriculture following their accession to the EU. On the other hand, a substantial reduction in the number of animals has led to a reduction in the use of pastures, a reduction in production and the use of inexpensive manure, and an increase in seasonal labor. As a result, unemployment and emigration are rising, employment chances and government tax revenues are decreasing, which also determines the need for higher subsidies. In conditions of monoculture, the reduction of soil fertility is becoming a major problem.

These processes in full-scale also apply to our country where the restructuring processes are markedly dynamic. The number of farms is now 201 thousand and is rapidly decreasing (over the past 10 years more than 2.45 times compared to 2007) This is mostly at the expense of small farms with an area up to 2 hectares which have fallen to 129000 . The specificity of Bulgarian agriculture is that the number of employees converted into annual work units in the sector is continuously decreasing since 2007 and in 2016 is $50 \%$ less than in 2007 , but the nominal number of employees was reduced by only $8 \%$. This means that agriculture continues to perform social functions as well.

\footnotetext{
${ }^{1}$ Business faculty, University of National and World Economy, Sofia, Bulgaria, juliadoj@abv.bg

${ }^{2}$ Business faculty, University of National and World Economy, Sofia, Bulgaria, albenakm@yahoo.com

${ }^{3}$ Faculty of economics, Trakia University, Stara Zagora, Bulgaria, dzaimova@gmail.com
} 
The purpose of this report is to assess the changes in agricultural development under the Common Agricultural Policy and the directions of the transition to sustainable agriculture.

\section{Transition from Productive to Post-Productive Models of Agriculture - Literature Review}

For decades, modernization of agricultural holdings and agricultural policy have focused on specialization, land consolidation and the reduction of production costs to meet the demand for lowercost foods (Kleinhanss et al., 2007; Bartolini and Viaggi, 2013). The economic benefits of agricultural productivity growth have been shifted to the rest of the economy by reducing real food prices for consumers and by releasing workers to the rapidly expanding non-agricultural sector.

Restricting market support mechanisms since 2000 have led to higher price volatility and the increased vulnerability of specialized farmers (Chatellier, 2011). Price volatility not only undermines long-term investment prospects (Sckokai and Moro, 2009) but also undermines the capacity of farms to absorb market shocks and thereby weakens their economic sustainability (Darnhofer, 2014). Market liberalization has raised the question for the farm model.

Some authors question whether this model supports sustainable agriculture (see for example Knickel et al., 2017; Ashkenazy et al., 2017) and attempt to revise the models of agricultural development that promote the achievement of economies of scale and economies of scope. Interestingly, the two strategies have the potential to reduce the average unit cost for producing a commodity but do this in different ways (Panzar and Willig, 1981).

Some researchers (Lockie et al., 2006) define the characteristics of productivity and post-productivism respectively as "intensification, concentration of production and specialization (farms and regions)", "extensification (reduction of external inputs and land use), access to land of the various stakeholders and diversification (heterogeneity in agriculture and other rural activities) "(page 38). Dualism of productivity and post-productivism was criticized at the theoretical level, taking into account the trend of post-productivist discourses, less attention is paid to the continuing importance of the production of basic goods in the rural economy (Wilson, 2001; Evans et al., 2002; Burton 2012). With reason some authors emphasize that the transition from the productivist to post-productivist model of transition is accompanied by a joint "temporary, sectoral and spatially" existence of both models (Wilson, 2001).

Ilbery and Bowler (1998) refer to the "known characteristics" of post-productivism and emphasize the "three bipolar dimensions of change" in agriculture, which include a shift from intensification to extensification, from concentration to dispersion and from specialization to diversification. These dimensions of change (albeit far from unquestionable) describe trends only in the agrarian sector without linking them to the consequences for rural areas and their inhabitants. In this sense, the research by Evans et al. (2002) can be considered as a successful attempt to address changes in agriculture and their relationship with rural change.

Critically evaluating and unifying the characteristics of the transition, as illustrated by Ilbery and Kneafsey (1997) and Ilbery and Bowler (1998), Evans et al. draws and justifies in five directions the transition from productivism to post-productivism. According to him, these are:

- the shift from quantity to quality in food production;

- increasing farm diversification and employment outside the farm;

- extending and promoting sustainable agriculture through agri-environment policy;

- diversification of production models and environmental regulation;

- restructuring state support for agriculture.

The second direction - increasing diversification in the economy and employment outside it - in fact means changing production patterns and diversifying them. Diversification is a prerequisite for creating new opportunities for creating added value based on emerging links between different activities and industries. And this means the emergence of new production models of multifunctional farms included in network structures and schemes guaranteeing the quality of agricultural products.

\section{Research methodology}

These reasons are the basis for modifying the approach of Evans et al. by combining it with the "bipolar characteristics of the changes" of Ilbery and Bowler (1998). 
- changing the focus of agricultural production - from quantity to quality in the production of products (or transition to quality);

- expand and promote sustainable agriculture through agri-environment policy and transition from intensification to extensification (or transition to sustainability);

- diversification of production models, raising income and preserving the environment (from specialization to diversification, from concentration to network structures of competitors);

- restructuring state support for agriculture.

Each of the listed trends in agriculture and rural development can be assessed with a number of indicators. For the purposes of our study, we chose indicators for assessing changes in the studied directions of change, listed in Table 1.

\begin{tabular}{|l|l|}
\hline \multicolumn{1}{|l|}{ Table 1: Methodological frame } \\
\hline Directions of changes to & \multicolumn{1}{c|}{ Indicators } \\
\hline quality & $\begin{array}{l}\text { i. a change in the importance (relative share) of organic production; } \\
\text { ii. a change in the number and relative share of bio-producers; } \\
\text { iii. Protected Geographical Indication Schemes (PGIS), Protected } \\
\text { Geographical Indication (PGI); } \\
\text { iv. a change in the number of agricultural holdings and the relative } \\
\text { share of network structures; }\end{array}$ \\
\hline sustainability & $\begin{array}{l}\text { i. a change in the number and relative share of agricultural holdings } \\
\text { applying agri-environment schemes; } \\
\text { ii. a change in applied plant production technology; } \\
\text { iii. a change in applied fertilization standards; } \\
\text { iv. a change in the use of plant and animal protection preparations; }\end{array}$ \\
\hline multifunctionality & $\begin{array}{l}\text { i. a change in the number of farms engaged in non-agricultural } \\
\text { activities; } \\
\text { ii. a change in the use of natural resources; }\end{array}$ \\
\hline $\begin{array}{l}\text { restructuring of state } \\
\text { support }\end{array}$ & $\begin{array}{l}\text { i. changes in support priorities } \\
\text { ii. decentralization of approaches, measures and means of support }\end{array}$ \\
\hline Source: Authors &
\end{tabular}

\section{Transfer to quality production and sustainable agriculture}

Changes in agricultural development cannot be assessed unambiguously. The importance of producing quality produce is increasing. At the end of 2017, the total number of organic operators registered in the Ministry of Agriculture, Food and Forestry is 6822, of which 6471 are producers, 181 processors of organic production, 169 traders. For the whole period 2006-2017, the number of organic farms has increased 30 times and the utilized agricultural land - 29 times (Figure 1). The size of the areas have grown strongly during the current program period and occupies $2.72 \%$ of the total utilized agricultural area in the country.

In 2017 the number of operators included in the control system of organic production represents $7.1 \%$ of the total registered 96476 farmers. By comparison, in the previous year, this share was $7.4 \%$ (Agrarian Report, 2018).

Organic livestock breeding is developing at a slower rate. In 2017, 10400 cattle, 25959 sheep, 9023 goats, are bred organically. That is $1-2 \%$ of the total farmed animals in Bulgaria. The relative share of organic beekeeping is the highest, with the number of bee families reaching 250434 or $31.35 \%$ of all bee families. The reasons for these rates of development are sought both in the increased consumer interest and quality and safety of products (Vasileva et al., 2018).

Together with the significant increase in the quality of production, there is an increase in the interest in registering protected geographical indications and traditional specialties guaranteed. At the end of 2018 there were registered two products with Protected Geographical Indication - Bulgarian Rose Oil and Gornooryahovski Sudjuk, 5 meat products under Traditional specialties guaranteed (EC, 2019). 


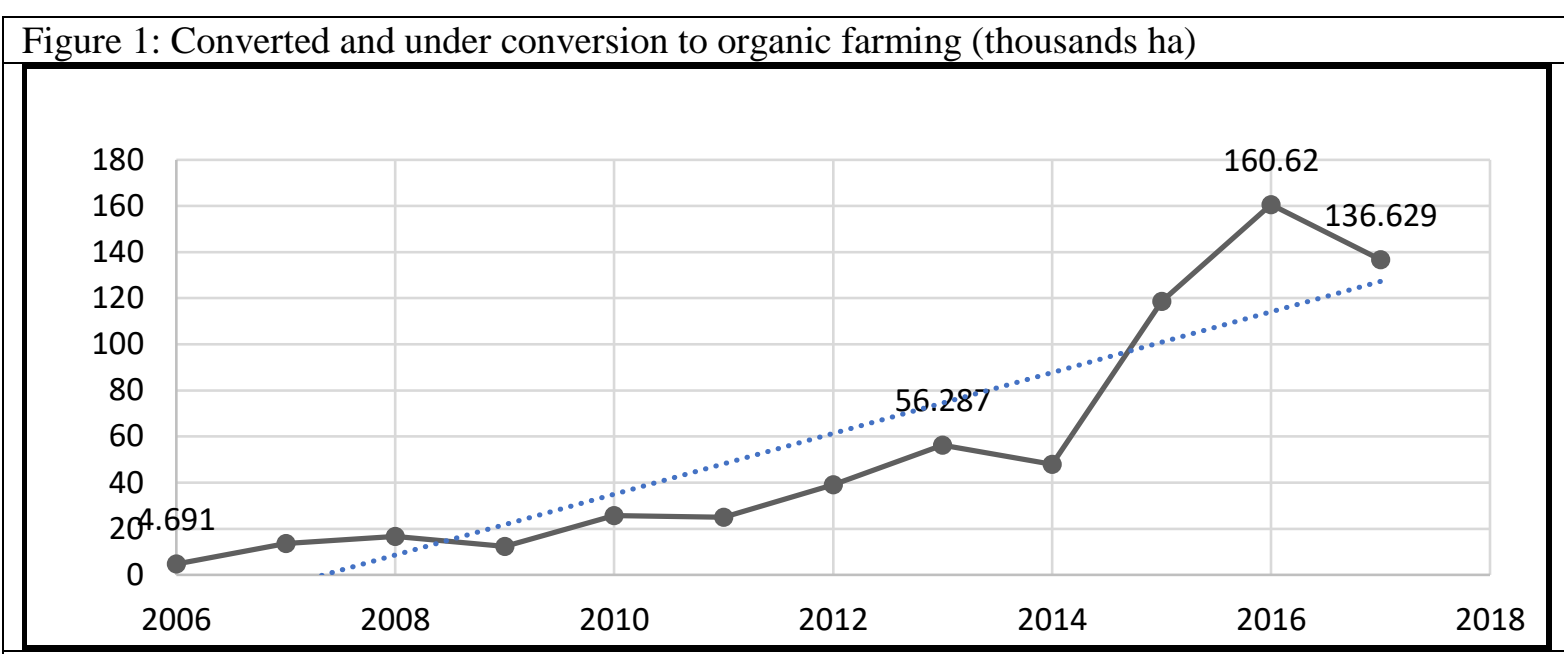

Source: Ministry of Agriculture, Food and Forestry, according to data of annual reports of controlling organic farming companies

Most numerous are the registered wines. 55 wines were accredited Protected Designation of Origin. In addition, for the product "Strandzha manov honey", the necessary documents were submitted and the product is in the process of being registered as a Protected Designation of Origin.

As a result of the ongoing organizational restructuring, the number of farms in Bulgaria is decreasing, but the relative share of small farms remains high. Nonetheless, there is little interest in association and participation in network structures. The producer organizations, supported by SAPARD, have also failed to consolidate. Many of them ceased operations.

Under the Rural Development Program (2007-2013) only 4 producer organizations were supported and 150 were planned for support. In the current programming period, 38 projects are under evaluation.

Interest in Agro-ecological schemes is generally great. The information in Table 2 shows that the RDP indicators for individual measures exceeded between $135 \%$ and $231 \%$.

\begin{tabular}{|l|c|c|c|}
\hline Table 2: Agri-ecological payments & $\begin{array}{l}\text { Number of } \\
\text { farms }\end{array}$ & Areas (ha) & $\begin{array}{l}\text { Rate of achievement of } \\
\text { the objectives (\%) }\end{array}$ \\
\hline Measures & 53802 & 359760 & 135 \\
\hline $\begin{array}{l}\text { 211 Payments for farmers' natural constraints } \\
\text { in mountain areas }\end{array}$ & 23136 & 257079 & 231 \\
\hline $\begin{array}{l}\mathbf{2 1 2} \text { Payments for farmers' natural constraints } \\
\text { in areas other than mountain areas }\end{array}$ & 10217 & 333884 & 183 \\
\hline $\begin{array}{l}\mathbf{2 1 3} \text { Natura 2000 payments and payments } \\
\text { related to Directive 2000/60 / EC (WFD) }\end{array}$ & & & \\
\hline
\end{tabular}

Source: MAFF, 2018.

Under Measure 214 "Agri-environment payments", several sub-measures have been implemented with the aim of: protecting biodiversity on an area of 13014 ha; improving water quality at 705 ha; and improving soil quality of 700,000 ha. Organic farming under the measure is supported in two directions - the area of organic plant growing is 29849 ha (the number of contracts is 1926) and for organic beekeeping - there are 307 contracts with 50909 bee hives.

Regarding applied technologies - an increase is observed in the areas where a conservation minimal treatment is applied, in which the soil layer is not turned and on the surface plant residues remain. They are already applied by $27 \%$ of the farms and on $41.2 \%$ of the total arable land.

The relative share of the areas fertilized by manure increased from $3.7 \%$ in 2013 to $5.3 \%$ in 2016 . As a result, the areas treated by artificial fertilizers (albeit slowly) have decreased from $76.1 \%$ to $72.3 \%$ over the same period.

In the opposite direction is the impact of the increase of the relative share of the areas treated with plant protection preparations which are chemical in origin. For a seven-year period, the areas where fungicides were used have grown most significantly, followed by insecticides and herbicides (Table 3). 
Table 3: Relative share of areas treated with herbicides, fungicides and others.

\begin{tabular}{|c|c|c|c|c|}
\hline \multirow{2}{*}{ Years } & $\begin{array}{c}\text { Utilized } \\
\text { Agricultural } \\
\text { Area (UAA) } \\
\text { greenhouses } \\
\text { excl. }\end{array}$ & $\begin{array}{c}\text { Share of UAA } \\
\text { with herbicides } \\
\text { application }\end{array}$ & $\begin{array}{c}\text { Share of UAA with } \\
\text { fungicides } \\
\text { application }\end{array}$ & $\begin{array}{c}\text { Share of UAA with } \\
\text { insecticides application }\end{array}$ \\
\cline { 2 - 5 } & Area (ha) & \% & $\%$ & \% \\
\hline $\mathbf{2 0 1 0}$ & 3615874,9 & 63,2 & 30,5 & 28.4 \\
\hline $\mathbf{2 0 1 3}$ & 3793833,8 & 74,2 & 47,1 & 39,5 \\
\hline $\mathbf{2 0 1 6}$ & 3794479,5 & 70,5 & 53,2 & 46,6 \\
\hline
\end{tabular}

Source: MAFF, Agrostatistics, 2012, 2015, 2018.

\section{Switching to new business models}

Adding value to agricultural products and developing other activities that diversify income sources are the main directions for the transition to multifunctionality of farms. Under the Rural Development Program, were created opportunities for the establishment of new micro-enterprises, development of tourism activities, etc. Although these opportunities were not used fully and the set objectives were not achieved, more than 1000 projects were realized and more than 2500 jobs were created (Figure 2).

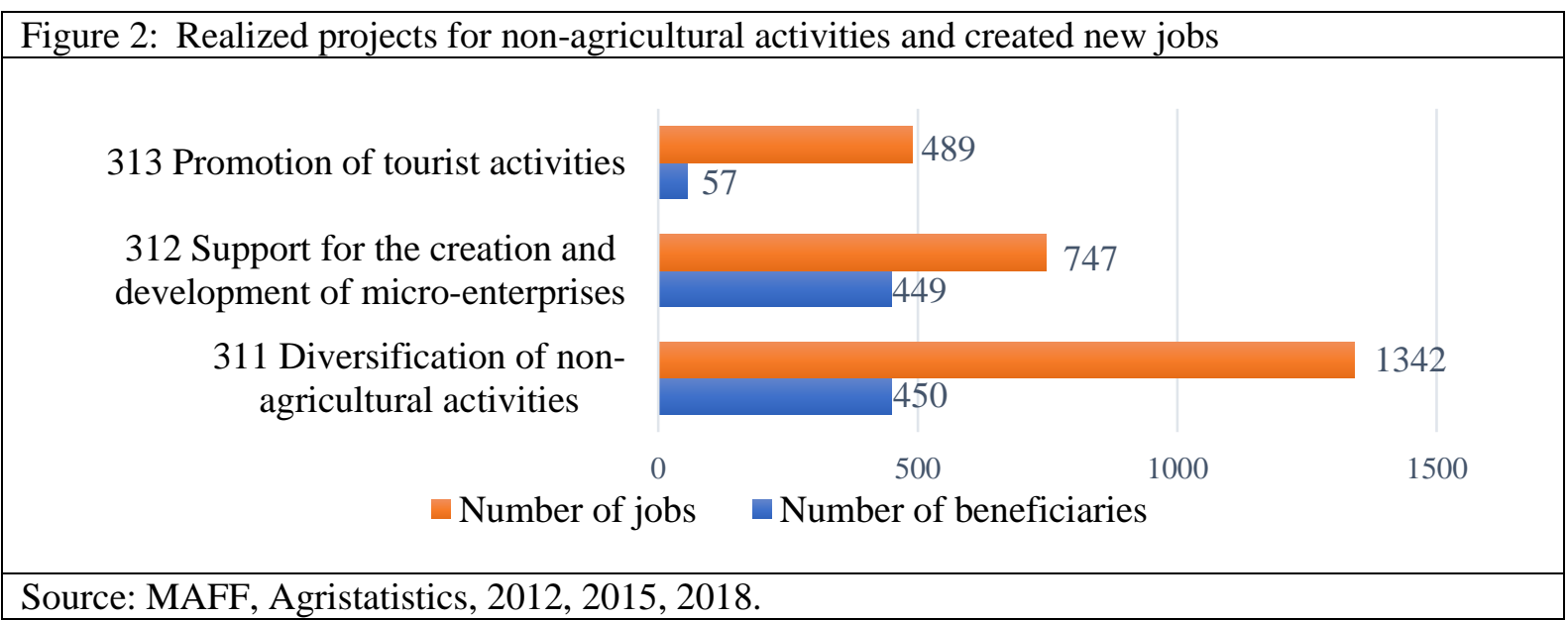

Under Measure 312 "Support for the creation and development of micro-enterprises", the greatest interest is shown in the development of tourism (61\% of the projects and 58\% of the funds) and in the construction of renewable energy sources $-29 \%$ of the projects and $33 \%$ of the funds under the measure were allocated for this purpose.

Despite this fact the number of farms performing other activities is decreasing (Doitchinova and Todorova, 2019) and in 2016 it totals 2093. Most numerous - 49.5\%, are the farms performing agricultural mechanized services, followed by those who process their output (14.9\%).

Changes in agrarian policy are aimed at national support for a number of traditional Bulgarian productions, as well as the introduction of a decentralized approach for the implementation of rural development programs.

\section{Conclusion}

The development of agriculture, the transition from one model to another in each country takes place at different paces under the influence of specific historical, economic, social and cultural conditions. Bulgaria's transition from a planned to a market economy, as well as land and structural reforms have hampered the introduction of innovative practices and technical solutions, slowing the process of modernization of production. As a result, the transition to sustainability is accompanied by continued mechanization and digitization of technological processes. There is a simultaneous development of both the productive and the post-productive model of agriculture. Together with the increasing interest in organic production, the implementation of environmentally friendly practices and the implementation of ecosystem services, the modernization based on computerization and chemisation continues. 
Part of the Common Agricultural Policy measures have not led to the expected changes and results and have become a prerequisite for increasing national programs and their support for the development of vegetable production, fruit growing, beekeeping, etc., as well as the establishment of a national program for the development of small farms.

All this has an impact on the development of rural areas, the opportunities for work and the living conditions in them. There will be a change in both the impact of agriculture on rural development and its role for the development of the regions.

\section{Acknowledgements}

The research leading to these results received funding from the Bulgarian Science Fund - project: "Sustainable multifunctional rural areas: rethinking agricultural models and systems with increased requirements and limited resources" (2017-2020).

\section{References}

Bartolini, F., Viaggi, D. (2013). The common agricultural policy and the determinants of changes in EU farm size. Land Use Policy 31, 126-135.

Burton, R.J.F., Wilson, G. (2012) The Rejuvenation of productivist agriculture: the case for "cooperative neo-productivism", Rethinking agricultural Policy Regimes: Food Security, Climate Change and the Future Resilience of Global Agriculture, Research in Rural Sociology and Development, Volume 18, 51-72.

Chatellier, V. (2011). Price volatility, market regulation and risk management: chal- lenges for the future of the CAP. INRA working Paper SMART e LERECO no 1104.

Darnhofer, I. (2014). Resilience and why it matters for farm management. Eur. Rev. Agric. Econ. 41 (3), 461-484.

Doitchinova, J., Todorova, K. (2019). From conventional to multifunctional farming: challenges and opportunities, in Sustainable agriculture and rural development in terms of the republic of Serbia strategic goals realization within the Danube region - sustainability and multifunctionality, Thematic proceedings, Institute of agricultural economics, Belgrade, 405-422.

EC, Agriculture and Rural Development, Agricultural market, wine, E-bacchus. Visited on 13.03.2019.

EC, Agriculture and Rural Development, Agriculture and Food, Door. Visited on13.03.2019.

EC (2010). The CAP towards 2020: Meeting the Food, Natural Resources and Territorial Challenges of the Future. COM, Brussels (2010) 672 final.

EC (2011). Sustainable Food Consumption and Production in a Resource-constrained World. Standing Committee on Agricultural Research (SCAR), Brussels.

Evans, N., Morris, C.,Winter, M. (2002). Conceptualizing agriculture: a critique of post-productivism as the new orthodoxy. Progress in Human Geography 26, 313-332.

Ilbery, B., Kneafsey, M. (1997) Regional images and the promotion of quality products and services in the lagging regions of the European Union. Paper presented to the Third Anglo-French Rural Geography Symposium, Université de Nantes, 11-14 September, 1997

Ilbery, B., Bowler, I. (1998). From agricultural productivism to post-productivism. In Ilbery, B. (Ed.), The Geography of Rural Change, Harlow, UK: Longman, 57-84.

Kleinhanss, W., Murillo, C., San Juan, C., Sperlich, S. (2007). Efficiency, subsidies and environmental adaptation of animal farming under CAP. Agric. Econ. 36 (1), 49-65.

Knickel, K. (1990). Agricultural structural change: impact on the rural environment. J. Rural Stud. 6 (4), 383-393.

Knickel, K. (1997). Changes in agricultural production and their potential impact on the development of rural areas. Q. J. Int. Agric. 36 (4), 353-378.

Knickel, K., Zemeckis, R., Tisenkopfs, T. (2013). A critical reflection of the meaning of agricultural modernization in a world of increasing demands and finite resources. In: Proceedings, vol. 6. ASU Publishing Center, Kaunas, Akademija, 561 567.

Ministry of agriculture, forestry and food (2018). Ex-post evaluation on Rural Development Program 2007-2013. FINAL REPORT

Sckokai, P., Moro, D. (2009). Modelling the impact of the CAP Single Farm Payment on farm investment and output. Eur.Rev.Agric.Econ. 36 (3), 395-423.

Vasileva, E., D. Ivanova, N. Tipova, S. Stefanov (2018) Quality of organic foods - a model for comparative analysis, Organic Agriculture, (2018). https://doi.org/10.1007/s13165-018-0211-4

Wilson, G.A. (2001). From productivism to post-productivism ... And back again? Exploring the (un)changed natural and mental landscapes of European agriculture. Transactions of the Institute of British Geographers, NS (26), 77-102. 